\title{
内視鏡下蝶口蓋動脈凝固術の有効性
}

\author{
新川智佳子*, 太田 伸男*, 稲村 和 俊**, \\ 古瀬 秀和 $* *$, 岡崎 買一***, 阿部 靖 弘***, \\ 青 柳優* \\ *山形大学医学部耳鼻咽喉科頭頸部外科, \\ **山形県立河北病院, ${ }^{* * *}$ 山形県立中央病院耳鼻咽喉科
}

\section{Efficiency in Endoscopic Sphenopalatine Artery Coagulation}

\author{
Chikako Shinkawa*, Nobuo Ohta*, Kazutoshi Inamura**, \\ Hidekazu Furuse***, Shinichi Okazaki***, Yasuhiro Abe***, \\ Masaru Aoyagi* \\ *Yamagata University, School of Medicine, Department of Otolaryngology \\ **Yamagata Prefectural Kahoku Hospital \\ ***Yamagata Prefectural Central Hospital
}

\begin{abstract}
Although non-surgical control of epistaxis by nasal packing is effective in many cases, the otolaryngologist may see some case of posterior epistaxis that become intractable and require repeated nasal packing. Between 2006 april and 2010 march, 12 patients with intractable posterior epistaxis -8 men and 4 women-were treated by endoscopic sphenopalatine artery coagulation with a harmonic scalpel at Yamagata university hospital and Yamagata Prefectural Central Hospital. Only one patient had subsequent epistaxis from Kiesselbach's plexus, 7 months postoperatively. Only one patient had a postoperative complication (acute sinusitis). Endoscopic coagulation may thus be appropriate for treating severe recurrent epistaxis refractory to repeated nasal packing.
\end{abstract}

Key words : intractable epistaxis, sphenopalatine artery, vidian neurectomy, harmonic scalpel

難治性鼻出血, 蝶口蓋動脈, 後鼻神経切断術, ハーモニックスカルペル

\section{1.はじめに}

鼻出血は日常診療でしばしば遭遇する疾患であり, 多 くはキーゼルバッハ部位からの出血であり, 出血点を確 認した上で止血も容易である。しかし鼻腔後方からの出 血や出血量が多い場合はしばしば出血点の同定が困難で 保存的治療に抵抗し，止血に難渋することもある。特 に, 高血圧の合併や抗凝固薬を内服している症例では出 血のコントロールに難渋することが多い。現在までべロ
ックタンポンの挿入によっても繰り返す鼻腔後方からの 鼻出血に対する観血的治療方法としては外頸動脈結禁 術，経上顎洞的顎動脈結紮術，顎動脈塞栓術等の有効性 が報告されてきた。今回我々は，蝶口蓋動脈由来の出血 と考えられ，保存的治療が奏功しない難治性鼻出血症例 に対し，後鼻神経切断術に準じた内視鏡下蝶口蓋動脈凝 固術を施行したので，その実際と成績について報告す る。

(2010年 6 月 28日受稿, 2010年 9 月 6 日受理)

連絡先, 別冊請求先 : 新川智佳子 $=990-2292$ 山形市大字青柳 1800 番地 山形県立中央病院耳鼻咽喉科

電話番号０23-685-2626 Mail : chikakoshinkawa@gmail.com 
表 1 内視鏡下蝶口蓋動脈凝固術を施行した12例

\begin{tabular}{|c|c|c|c|c|c|c|c|c|c|c|}
\hline \multirow{2}{*}{$\begin{array}{l}\text { 症 } \\
\text { 例 }\end{array}$} & \multirow{2}{*}{$\begin{array}{c}\text { 年齢 } \\
\text { 性 }\end{array}$} & \multirow[b]{2}{*}{ HT } & \multirow{2}{*}{$\begin{array}{l}\text { 抗血小板薬 } \\
\text { 抗凝固薬 }\end{array}$} & \multirow[b]{2}{*}{ 出血部位 } & \multicolumn{2}{|c|}{ 手術 } & \multirow{2}{*}{$\begin{array}{l}\text { 手術 } \\
\text { 時間 }\end{array}$} & \multirow{2}{*}{$\begin{array}{l}\text { 術後合 } \\
\text { 併症 }\end{array}$} & \multirow[b]{2}{*}{ 術後鼻出血 } & \multirow{2}{*}{$\begin{array}{l}\text { 経過観 } \\
\text { 察期間 }\end{array}$} \\
\hline & & & & & $\begin{array}{l}\text { 蝶口蓋動脈凝固術 } \\
+ \text { +下甲介切除術 }\end{array}$ & その他 & & & & \\
\hline 1 & $\begin{array}{l}74 \\
\text { 女 }\end{array}$ & - & - & 右後方 & 両側 & & $2: 18$ & - & - & $3 y 8 m$ \\
\hline 2 & $\begin{array}{l}57 \\
\text { 男 }\end{array}$ & - & - & 左後方 & 両側 & & $0: 56$ & - & - & $3 y 11 \mathrm{~m}$ \\
\hline 3 & $\begin{array}{l}34 \\
\text { 男 }\end{array}$ & - & - & 左後方 & 左側 & & $1: 05$ & $\begin{array}{l}\text { 左上顎 } \\
\text { 洞炎 }\end{array}$ & - & $1 \mathrm{y} 8 \mathrm{~m}$ \\
\hline 4 & $\begin{array}{l}27 \\
\text { 男 }\end{array}$ & - & - & $\begin{array}{l}\text { 右中鼻道 } \\
\text { 後方 }\end{array}$ & 右側 & 右沉副鼻腔手術 & $2: 02$ & - & - & $4 \mathrm{~m}$ \\
\hline 5 & $\begin{array}{l}61 \\
\text { 男 }\end{array}$ & - & - & $\begin{array}{l}\text { 左中鼻道 } \\
\text { 後方 }\end{array}$ & 左側 & 左上顎洞篩骨洞根本術 & $0: 45$ & - & - & $1 \mathrm{y} 6 \mathrm{~m}$ \\
\hline 6 & $\begin{array}{l}73 \\
\text { 男 }\end{array}$ & - & - & 左後方 & 両側 & & $1: 10$ & - & $\begin{array}{c}+ \\
\text { 右 Kiesselbach }\end{array}$ & $1 \mathrm{y} 1 \mathrm{~m}$ \\
\hline 7 & $\begin{array}{l}62 \\
\text { 男 }\end{array}$ & + & - & 左後方 & 両側 & $\begin{array}{l}\text { 両上顎洞篩骨洞根本 } \\
\text { 術, 抜歯術, 粘膜弁に } \\
\text { よる瘻孔閉鎖術 }\end{array}$ & $3: 22$ & - & - & $1 \mathrm{y} 1 \mathrm{~m}$ \\
\hline 8 & $\begin{array}{l}77 \\
\text { 女 }\end{array}$ & + & + & 左後方 & 両側 & & $1: 19$ & - & - & $1 \mathrm{y} 1 \mathrm{~m}$ \\
\hline 9 & $\begin{array}{l}89 \\
\text { 女 }\end{array}$ & + & + & $\begin{array}{l}\text { 左中鼻道 } \\
\text { 後方 }\end{array}$ & 両側 & & $1: 05$ & - & - & $6 \mathrm{~m}$ \\
\hline 10 & $\begin{array}{l}62 \\
\text { 男 }\end{array}$ & + & - & 右後方 & 右側 & & $0: 38$ & - & - & $5 \mathrm{~m}$ \\
\hline 11 & $\begin{array}{l}55 \\
\text { 男 }\end{array}$ & + & + & $\begin{array}{l}\text { 左中鼻道 } \\
\text { 後方 }\end{array}$ & 両側 & & $1: 37$ & - & - & $3 \mathrm{~m}$ \\
\hline 12 & $\begin{array}{l}82 \\
\text { 女 }\end{array}$ & + & + & 左後方 & 左側 & & $0: 50$ & - & - & $3 \mathrm{~m}$ \\
\hline
\end{tabular}

\section{2. 対象症例と結果}

2006年 4 月以降, 山形大学医学部付属病院耳鼻咽喉 科, 山形県立中央病院耳鼻咽喉科において難治性鼻出血 と判断され，後鼻神経切断術に準じた内視鏡下蝶口蓋動 脈凝固術を行った症例は12例であった（表 1 ）。全例明 らかな出血点が確認できなかったが，鼻腔後方の蝶口蓋 動脈由来の出血と考えられ, 保存的な治療に奏功せず止 血に難渋した症例であった。

12例中，男性 8 例，女性 4 例で，年齢は平均 62.75 歳 （27～89歳）であった。合併症として 6 例で高血圧の治 療中であり，4例で抗凝固薬もしくは抗血小板薬を内服 していた。これらの症例に対し後鼻神経切断術に準じた 内視鏡下蝶口蓋動脈凝固術を施行した。

手術は 7 例で両側, 5 例で患側のみ行った。副鼻腔炎
を合併している症例では病変に応じて内視鏡下鼻副鼻腔 手術を併せて施行した。

術後合併症としては 1 例で急性上顎洞炎を認めた。3 年 8 ケ月から 3 ケ月の経過観察期間で現在までに蝶口蓋 動脈領域からの再出血は認めていないが， 1 例で術後 7 ケ月目に患側のキーゼルバッハ部位からの出血を認めた が，容易に止血可能だった。

\section{3. 内視鏡下蝶口蓋動脈凝固術の実際}

はじめに明らかな出血点を同定するためによく鼻内を 観察し，蝶口蓋動脈領域からの出血が疑わしいことを確 認した上で手術操作を開始した。

まずワーキングスペースを確保するために粘膜下下鼻 甲介切除を行った。粘膜下下鼻甲介切除術は川合らの方 法に準じ下甲介内側の粘膜を下鼻甲介骨から剥離し，下 


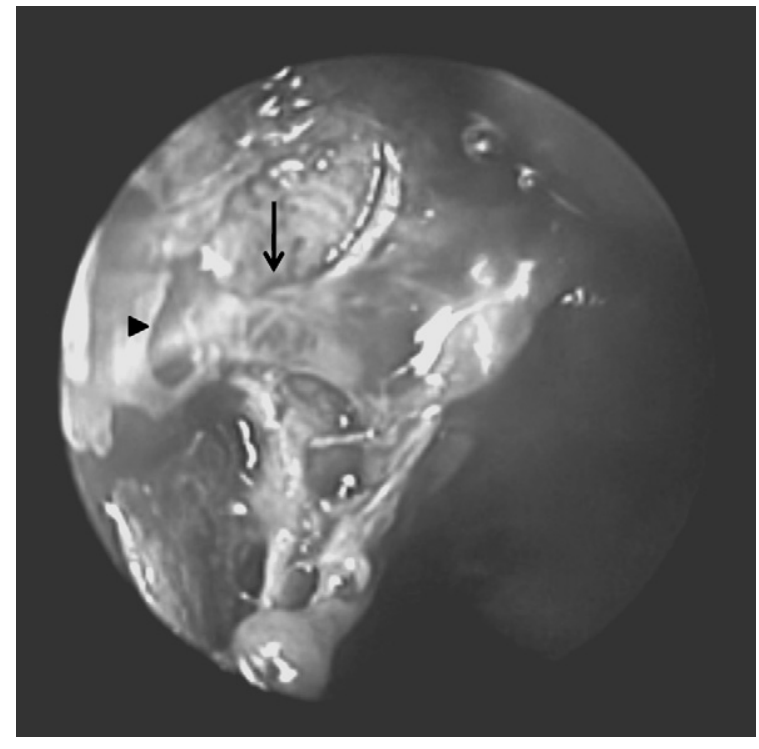

図 1 右内視鏡下蝶口蓋動脈凝固術 上顎洞自然孔後方で粘膜骨膜弁を挙上し，蝶口蓋 孔（矢頭）から出る蝶口蓋動脈（矢印）を同定し た。

鼻甲介骨と外側粘膜を切除した上で，下鼻甲介骨切断端

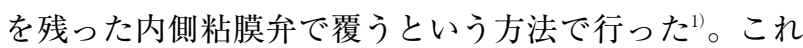
により術後長期の痂皮形成を防ぐことが期待できる。次 に上顎洞自然口後方，口蓋骨垂直板の部位で骨膜下に粘 骨膜弁を剥離すると蝶口蓋動脈が索状の構造物として確 認された（図 1 )。蝶口蓋動脈と思われる索状物が拍動 していることを確認することも大切である。ジョンソ ン・エンド・ジョンソン社ハーモニックスカルペルを用 いて蝶口蓋動脈凝固・切離を行った。当科ではブレード はフック型，設定はパワーレベル 3 で行っている。実際 にはこの索状物から蝶口蓋動脈のみを同定するのは困難 な場合が多く，後鼻神経と併せて切断することもある。 切離後の蝶口蓋動脈が蝶口蓋孔に陥入し，断端から出血 することも考えられため, 凝固・切離はなるべく遠位で 行うよう心がけている。また，ブレードのフックに蝶口 蓋動脈を引っ掛けて切断できるよう, 十分に蝶口蓋孔を 露出するということも注意点の一つである。最後に剥離 した骨粘膜弁を用いて露出した蝶口蓋孔を可及的に被覆 した。鼻腔の容量に応じてテラマイシン軟膏を塗布した ガーゼを鼻内に挿入し手術を終了とした。

\section{4. 代表症例}

患者：74歳

主訴：両側鼻出血

既往歴: 平成 9 年, 右鼻出血に対し右顎動脈塞栓術。 平成12年に左鼻出血に対し左顎動脈塞栓術。以後, 2 回
の難治性鼻出血での入院歴があり。その他降圧薬や抗凝 固薬等の内服は行っていなかった。

現病歴（図 2）：平成19年12月19日，両側鼻出血を認 め, 前医入院。出血点は鼻腔後方が疑われたが特定でき ず,タンポンガーゼを挿入し出血は落ち着いていたが, 12 月23日, タンポンガーゼ抜去後, 再出血があり, 再度夕 ンポンガーゼを挿入したにも関わらず出血コントロール が不能であったため，12月27日，当院転院となった。

現症：当科転院時は両側鼻腔内にガーゼがつめられた 状態で，咽頭に出血の流出は認めなかった。

血液生化学検査：血液検査上は軽度貧血を認めるのみ で，血小板減少や凝固系に異常は認められなかった。

CT（図 3 ）：副鼻腔 CT では出血の原因となるような 腫瘍性病変は認められなかった。

経過（図 2 ）：当科転院後は再出血を認めなかったの でH20年 1 月 3 日，両側タンポンガーゼを抜去した。そ の後も鼻出血なく経過していたが，1月11日，特に誘因 なく右鼻出血あり，この時もキーゼルバッハ部位からの 出血ではなく，明確な出血点は明らかではなかったが鼻 腔後方からの出血, つまり蝶口蓋動脈領域からの出血が 疑われたため，小児用フォーレ，タンポンガーゼを挿入 した。それまでの既往や経過から保存的加療で止血は困 難と考え，1月13日，全身麻酔下に後鼻神経切断術に準 じて両側蝶口蓋動脈凝固術を施行した。術後出血は認め ず，術後 7 日にガーゼ抜去を抜去し，その後も鼻出血を 認めなかったため，術後16日で退院となった。術後 9 ケ 月目に再診した際は鼻出血を含め自覚症状はなく, 鼻内 も再出血の兆候や鼻内泇皮を認めなかった（図 4 ）。

\section{5. 考 察}

現在まで，難治性鼻出血に対する観血的治療方法とし ては従来行われてきた外頸動脈結紮術に代わり，経上顎 洞的顎動脈結禁術，顎動脈塞栓術などの有効性が報告さ れてきた ${ }^{2)}$ 。しし，これらの術式も重大な合併症や限 られた症例や施設でしか施行できないなどの欠点もあ る。経上顎洞的顎動脈結紮術は下眼窩神経の障害や上顎 洞瘻孔など歯齦部切開に伴う合併症をきたす可能性があ る る $^{34}$ 。また，上顎洞の発育が悪い症例や上顎洞手術の既 往のある症例，粘膜腫脹等で上顎洞内が充満している症 例では適応とならない場合もある ${ }^{2,5)}$ 。顎動脈塞栓術も出 血部位や出血側の同定が困難な場合でも適応となるとい う利点はあるが，まれに血管損傷や脳梗塞等の重篤な合 併症を生じる可能性もあり，また熟練した放射線科医と の連携が必要であるため, 施行可能な施設が限られると いう欠点がある ${ }^{2,3)}$ 


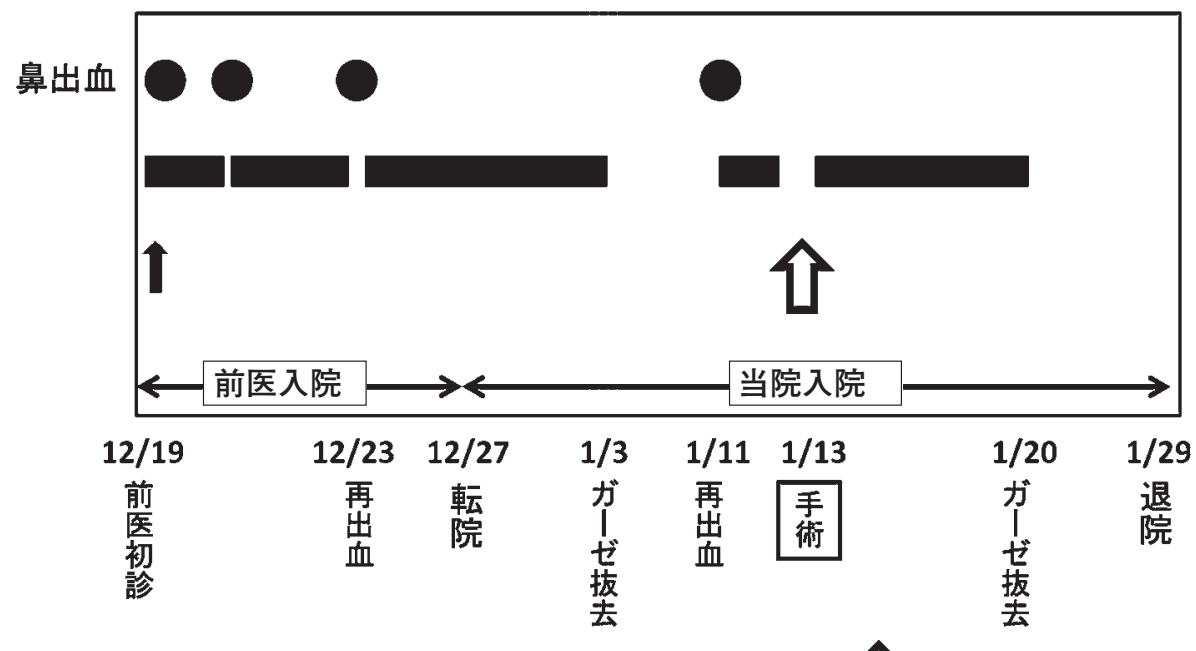

\section{タンポンガーゼ挿入期間 1 粘膜焼灼術 才蝶口蓋動脈㠜固術}

図2 治療経過

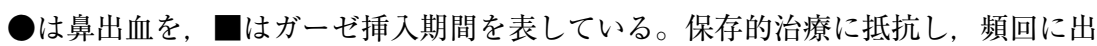
血を繰り返していることが分かる。
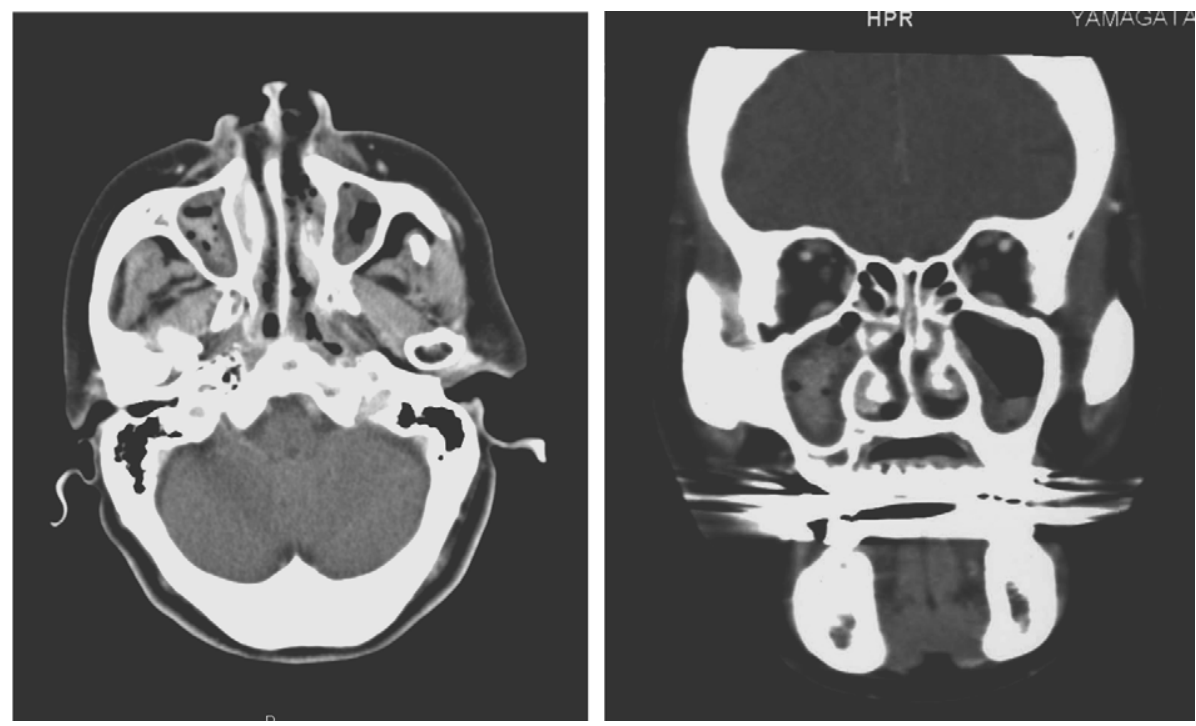

図3 副鼻腔 CT

出血の原因となるような腫瘍性病変はなかった。

近年内視鏡手術の発達に伴い, 鼻出血症例に対しても 様々な内視鏡下止血術の報告が応用されている2.6 -8)。吸 引管モノポーラを用いた止血術6 や内視鏡下経中鼻道的 もしくは経鼻中隔的に蝶口蓋動脈をクリッピングする方 法3.6.11, 12) などの有効性が報告されている。

当科でも2006年以降，鼻腔後方からの出血で難治性鼻 出血に対しハーモニックスカルペルを用いた内視鏡下蝶 口蓋動脈凝固術を行っている。この術式は後鼻神経切断 術に準じて施行できるため，比較的手技が容易で低侵襲 であるという利点がある。また合併症として重篤なもの は比較的少なく, 鼻内泇皮, 歯・上口唇・口蓋のしびれ 等があげられている ${ }^{13)}$ 。
再出血率は経上顎洞的顎動脈結紮術, 顎動脈塞栓術で それぞれ $12 \% ， 20 \%$ との報告されているのに対し ${ }^{3)}$ ，蝶 口蓋動脈クリッピング術では $12 \%{ }^{13)}$ との報告があり, 当 科で行っている内視鏡下蝶口蓋動脈凝固術では 1 例のキ 一ゼルバッ八部位からの鼻出血を認めたのみで，他の治 療方法と比較しても良好な治療成績が期待できると考え られた。また，現在までに蝶口蓋動脈からの再出血をみ とめておらず，ハーモニックスカルペルを用いた内視鏡 下蝶口蓋動脈凝固術は有効な観血的治療方法の一つと考 えられた。具体的にこの術式の適応については, 蝶口蓋 動脈領域からの再出血率が高いということを考慮に入れ なければならない。藤谷らの報告ではキーゼルバッ八部 

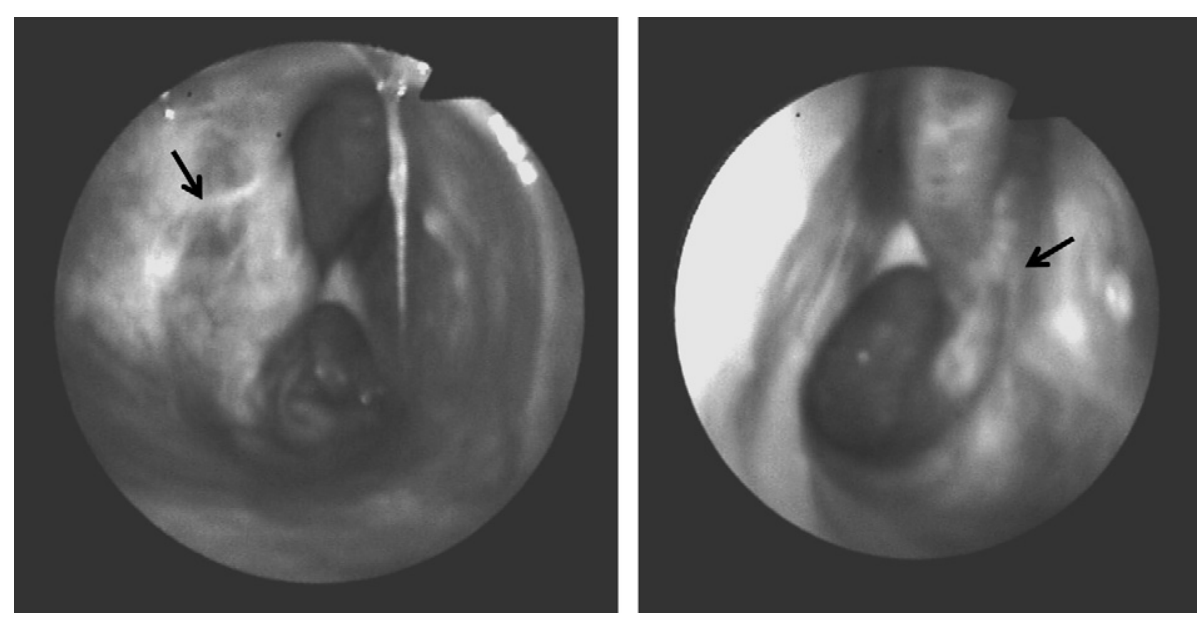

図4術後 9 ケ月目の鼻内所見

凝固部位（矢印）に再出血の兆候はみられず，鼻内に痂皮形成も認めなかった。

位以外の出血では非常に再出血率が高いことが報告され ている ${ }^{14)}$ 。また基礎疾患として, 高血圧症を有する患者 の再出血率が $25 \%$, 心疾患を有する患者の再出血率が $63 \%$ と報告されており ${ }^{14)}$, ハーモニックスカルペルを用 いた内視鏡下蝶口蓋動脈凝固術は以下のような症例で有 効な治療法の一つと考えられる。(1)出血部位がキーゼル バッハ部位ではなく鼻腔後方からの出血で, 蝶口蓋動脈 領域からの出血と考えられる症例，(2)抗血小板薬や抗凝 固薬を継続して服薬する必要があり，今後も鼻出血を繰 り返す可能性のある症例, (3)鼻腔悪性腫瘍や血管腫をは じめとした腫瘍性病変や血液疾患など出血性素因となる ような基礎疾患がない症例, (4)熟練した耳鼻科医の止血 処置にも抵抗し頻回に鼻出血を繰り返すような難治性鼻 出血の症例，である。

当科では術側の決定は基本的には患者の希望により決 定している。患者は繰り返す鼻出血とそれに対する頻回 の鼻処置を経験しているため, 鼻出血に対する恐怖感が 強く, 患側のみではなく, 今後出血するリスクの否定で きない健側の手術も希望することが多い。また，他の動 脈支配領域からの代償性出血が約 1 ～2\%でみられると の報告があり ${ }^{6)}$, それについても術前に患者に十分なイ ンフォームドコンセントを行う必要がある。両側蝶口蓋 動脈凝固術を行ったために, 両側粘膜下下鼻甲介切除術 を施行する必要があり，これに伴う鼻内泇皮等の術後合 併症もあるが，現在まで当科では健側も同時に手術する ことによる合併症はみられていない。粘膜下下鼻甲介切 除術を行うことによって術中のワーキングスペースが確 保され，手術操作が容易になるだけでなく，術後の鼻内 の観察が容易になり, 再出血時の処置も容易になると考 えられる。

また凝固の手段として当科ではハーモニックスカルペ
ルを用いている理由として，ハーモニックスカルペルは 超音波振動メスであり，超音波振動による蛋白変性およ び摩擦熱による凝固作用が発生するため, 電気メスやレ ーザーと違い, 低温で周囲の組織への熱損傷を最小限に 抑えることができる ${ }^{15)}$ 。また，ハーモニックスカルペル は切開と凝固が同時に行えるというのも大きな利点に一 つである。しかし，ハーモニックスカルペルはコストが 高いという欠点があり, 今後の課題の一つである。また, 術後再出血の有無を引き続き経過観察していく予定であ る。

\section{参考文献}

1 ）川合正和, 吉田美加, 金 慶訓, 他 : 粘膜下下甲介 切除術変法. 耳鼻臨床 補 $1991 ; 51 ： 133-7$.

2）夜陣紘治, 立川隆治：鼻出血の手術的治療. JOHNS 2000；10：1629-33.

3 ）清水猛史, 瀬野悟史, 有方雅彦, 他 : 内視鏡下鼻副 鼻腔手術における留意点とコツ 鼻出血. JOHNS $2008 ; 2$ : 234-8.

4 ) Cullen MM, Tami TA : Comparison of internal maxillary artery ligation versus embolization for refractory posterior epistaxis. Otolaryngol Head Neck Surg 1998; 118 : 636-42.

5 ）井口芳明, 八尾和雄, 西山耕一郎, 他：手術治療を 必要とした鼻出血症例の臨床的検討. 耳鼻臨床 $2003 ; 6: 541-7$.

6 ）久保伸夫：鼻出血の手術的治療. JOHNS 2005; 7 : 995-1001.

7 ）黄川田徹：難治性鼻出血に対する鼻副鼻腔手術一出 血点の同定と内視鏡下蝶口圔動脈凝固術一. JOHNS 2002; 9 : 1527-32. 
8 ）中村光士郎：難治性鼻出血に対する内視鏡下止血 法. 日鼻誌 $2003 ; 42: 8-12$.

9 ) Budrovich R, Saetti R: Microscopic and endoscopic ligature of the sphenopalatine artery. Laryngoscope 1992 ; 102 : 1390-4.

10) Voegels RL, Thome DC, Iturralde PPV, et al : Endoscopic ligature of sphenopalatine artery for severe posterior epistaxis. Otolaryngol Head Neck Surg $2001 ; 124: 464-7$.

11）有方雅彦，瀬野悟史，鈴木幹男，他：難治性鼻出血 症例の検討一鼻内視鏡下血管クリッピングを中心 に一. 日耳鼻 $2006 ; 109: 649-54$.

12) Seno S, Arikata M, Sakurai $H$, et al: Endoscopic ligation of the sphenopalatine artery and the maxillary artery for the treatment of intractable posterior epistaxis. Am J of Rhinology \& Allergy 2009; 2 : 197-9.

13) Snyderman CH, Goldman SA, Carrau RL, et al: Endoscopic sphenopalatine artery ligation in an effective method of treatment for posterior epistaxis. Am J Rhinol 1999 ; 13 : 137-40.

14）藤谷 哲，篠 美紀，洲崎春海：高齢者の鼻出血. JOHNS $2000 ； 10$ : 1615-8.

15）松尾博道: 鼻出血の止血材料. JOHNS 2005; 7 : 1023-8. 